\title{
Corporate Governance and Firms'Financial Performance of Listed Company in the West African Monetary Union (Wamu) Regional Financial Exchange
}

\author{
Aboudou Maman Tachiwou ${ }^{1}$ \\ ${ }^{1}$ Faculté des Sciences Economiques et de Gestion (FASEG), Université de Lomé, Togo \\ Correspondence: Aboudou Maman Tachiwou, Faculté des Sciences Economiques et de Gestion (FASEG), \\ Université de Lomé, Togo. E-mail: amtwatara@ hotmail.com
}

Received: March 29, 2016

Accepted: June 14, 2016

Online Published: July 25, 2016

doi:10.5539/ijef.v8n8p212

URL: http://dx.doi.org/10.5539/ijef.v8n8p212

\begin{abstract}
This study examines empirically the impact of corporate governance mechanisms on firm financial performance using listed firms in the West African Monetary Union (WAMU).Based on the review of existing literature, four corporate governance variables were selected namely: composition of board member, board size, CEO status and ownership concentration which served as the independent variables. The ordinary least square regression was used to estimate the relationship between corporate governance and firm performance. A total of 39 firms were selected for the study cutting across all sectors of Regional Financial Exchange. Findings from the study show that there is positive and significant relationship between composition of board member and board size as independent variables and firm performance. CEO status also has positive relationship with firm performance but insignificant at $\mathrm{P}<0.05$. However, ownership concentration has negative relationships with return on asset (ROA) but positive relationship with profit margin (PM). The relationships are not significant at 5\%.A high concentration of shares tends to create more pressure on managers to behave in ways that are value-maximizing.
\end{abstract}

Keywords: corporate governance, financial performance, West African Monetary Union (WAMU)

\section{Introduction}

This study sets to discus an analysis of the effect of corporate governance on financial performance of listed firms in the West African Monetary Union (WAMU). General ideas have surfaced and resurfaced many times that the governance structure and control mechanisms of corporate entity significantly impact corporation ability to respond positively to both internal and external factors and thus have a support on performance. We extend this literature by examining the corporate-governance connection in West African Monetary Union which presents a number of key traits for business and governance practices as it is well established that there are dissimilarity in the corporate governance practices between countries.

Several studies have supplied the link between corporate governance and firm performance. Bebchuk, Cohen, and Ferrell (2004) posit that "a well governed firm has higher firm performance"; Gompers, Ishii, and Metrick (2003) show through their study that firms with poor corporate governance quality enjoy lower stock returns than those with a higher level of governance quality. Financial havoc of many corporations such as those of USA, South East Asia and Europe have been premised on the misfiring of corporate governance; lofty profile scandals throughout the world such as Enron and World.Com in the United States, Transmile, Megan Media and Nasioncom in Malaysia bring about the importance of good corporate governance to limelight. Each of these corporate cases was directly bound to corporate governance defeat (Hussin \& Othman 2012; Abdul-Qadir \& Kwambo, 2012).

The overall objective of this study is to look into the link between corporate governance and firm financial performances in West African Monetary Union (WAMU). Specifically, the study seeks to:

$\checkmark \quad$ Investigate the influence of the composition of board members on firms' financial performance;

$\checkmark \quad$ Analyze the relationship between board size and firms' financial performance;

$\checkmark \quad$ Find out whether or not the separation of the posts of CEO (Chief Executive Officer) and board chair is of any value in the promotion of firms' financial performance; and 
$\checkmark$ Look into the extent to which shareholding may be related to firms' financial performance.

\section{Research Hypotheses}

In line with the research objectives, the hypotheses to be tested in this study are:

$\checkmark \quad$ There is a significant link between composition of board directors and firms' financial performance;

$\checkmark \quad$ There is a significant connection between board size and firms' financial performance;

$\checkmark$ There is a significant connection between ceo status and firms' financial performance;

$\checkmark \quad$ There is significant relationship between ownership concentration and firms' financial performance.

This study will therefore fill a gap in the literature by examining the nexus between performance and corporate governance practices of firms generally and specifically the corporate governance practices in West African Monetary Union firms. Furthermore, it will add to the general body of literature the impact of corporate governance and performance of firms in West African Monetary Union. The rest of the paper is structured as follows: section 2 presents literature inculcating the conceptual framework, corporate governance mechanisms, theoretical framework and empirical review on relationship between corporate governance and firm financial performance. Section three presents the methodology. Section four focuses on results, finding and discussions. Section five presents the further analysis of the study. Lastly, conclusions and recommendations are suggested in section six.

\section{Literature Review}

The role of corporate governance has been identified as essential to company performance and this is so because of the trend for managers and some other stakeholders to engage in unethical business practices that may undercut the rights of "less informed" stakeholders in corporate organizations (Agbonifoh, 1999). These immoral practices include manipulation with the financial statements to give wrong impression of the financial health of the organization to the recipients of these reports, Africa. Many firms present deceptive information on its financial statement (Onyenankeya, 2003).

Corporate governance is about promoting corporate fairness, transparency and accountability (Glossary, 2013). While Adedotun (2003) sees corporate governance as the frame for accounting for decision making, it is the efficient management of relationship within the organization integrity to improve firm performance for the advantage the stakeholders. Okeahalam and Akinboade (2003) outlined specific advantage of corporate governance to include ethical wholeness in the midst of organization strength and it could be counted upon to safeguard the resources and entitlements of all stakeholders. Also, it enhances the confidence of the investing public and attracting foreign investors to the firms in particular and the economy in general. Corporate governance improves the performance and assures the conformance of corporate to develop and steadying a business environment that stimulates managers and entrepreneurs to maximize firm returns on investment, operational efficiency and long-term productivity growth. The final outcome of these corporate governance advantages are higher cash flows and superior performance of the company (Love, 2011).

Emerging economy like West African Monetary Union needs good governed and managed business enterprises or organizations that can promote investment, create jobs and wealth for the population, remain viable, sustainable and competitive in the global market. Good corporate governance is a precondition for national economic development. The focus of this section is to examine some fundamental concepts that relate to the subject matter.

\subsection{The Impact of Corporate Governance on Firm Performance}

The World Bank, in 1999, states that corporate governance comprises two mechanisms, internal and external corporate governance. Internal corporate governance, giving precedence to shareholders' interest, operates on the board of directors to monitor top management. On the other hand, external corporate governance instructor and controls managers' behaviors by means of external regulations and force, in which many parties involved, such as suppliers, debtors, accountants, lawyers, providers of credit ratings and investment bank.

\subsubsection{Board Structure}

Veliyath (1999) highlights that the board serves as a bridge between owners and managers; its obligation is to protect shareholders' interests. Specifically speaking, taking responsibility for managing and supervising, the board should instructor managers' behaviors for shareholders' interests, make important decisions, employ management team and monitor firms to obey the law of shareholders.

Jensen (1993) reveal that directors in a large board have several opinions and consensus is hard to reach, then the 
effectiveness being lower, the situation could damage if directors increase (Lipton \& Lorsch, 1992).

A board encompasses internal and external directors. Fama and Jensen (1983) find that internal directors, by virtue of their positions, have much more information, are likely to collude with managers and make decisions against shareholders. By comparison, external directors in neutral position, acting as supervisor, are good for evacuation principal-agency problem. Like Fama and Jensen (1983); Jensen and Meckling (1976); Daliy and Dalton (1993); Patton and Baker (1987); and Dahya, Lonie, and Power (1996) show that CEO duality could bring about negative effects for corporate performance. Nonetheless, in accordance with stewardship theory, executives' responsibility may neutralize self-interest behaviors derived from CEO duality, and they are yet much more devoted to advance corporate performance. Boyd (1995) approve to that CEO duality inject in positive effects for corporate performance.

\subsubsection{Ownership Structure}

Berle and Means (1932) indicate that ownership dispersion involve management which is distinguished from ownership, which, as Jensen and Meckling (1976) underline, may contribute to agency problems amongst managers and shareholders or agent and principal. Furthermore, Shleifer and Vishny (1986) and Morck, Shleifer, and Vishny (1988) detect the phenomenon of ownership concentration.

Kao, Chiou, and Chen (2004) reveal that firms in financial distress are closely related to high ratio of the shares pledged by directors, causing concern about the agency problem resulting from the pledge of corporation shares. Chiou, Hsiung, and Kao (2002) point out that, directors and supervisors could fund by the collateralized shares and further purchase more firm stocks to handle stock price or improve their power. Directors' and supervisors' financial stress, because of the collateralized shares, is closely related to share price. Share price collapses, the value of the collateralized shares downgrade and even drops below the standard of the required margin; correspondingly, collateralizing shareholders will be requested to collateralize more shares while debtors fail to afford more shares as collaterals, financial institutions as creditors will close the position of collateralized shares. As a result, collateralizing shareholders, making use of their position, may make a prey of small shareholders or embezzle company funds.

\subsection{Review of Related Corporate Governance Theories}

Corporate Governance theories range from the agency theory and expanded into stewardship theory, political theory, resource dependency theory, stakeholder theory, transaction cost theory and ethics related theories such as virtue ethics theory, business ethics theory, feminist's ethics theory, discourse theory to postmodernism ethics theory. The following are the review of little of the related theories to the study.

Corporate governance is the relationship among shareholders, board of directors and the top management in determining the direction and performance of the corporation. It includes the connections between the many players involved (the stakeholders) and the aims for which the corporation is governed (Kim \& Rasiah, 2010). There are a number of theoretical outlooks which are used in explaining the effect of corporate governance mechanisms on firm's financial performance. The most important theories are stakeholder's theory, the agency theory and resource dependency theory (Maher \& Andersson, 1999).

\subsubsection{Agency Theory}

The agency theory a neoclassical economic theory (Ping \& Wing, 2011) is usually the starting point for any debate on the corporate governance. The theory is based on the concept of separation of ownership (principal) and management (agent). It states that "in the presence of information asymmetry the agent is likely to pursue interest that may hurt the principal (Sanda, Mikailu, \& Garba 2005). It is earmarked on the hypothesis that: parties who enter into a contract will act to maximize their own self-interest and that all actors have the liberty to enter into a contract or to contract elsewhere.

\subsubsection{Stakeholders' Theory}

The stakeholders' theory was adopted to fill the observed insufficiency created by omission found in the agency theory which identifies shareholders as the only interest group of a corporate entity. Within the framework of the stakeholders theory the problem of agency has been broaden to incorporate multiple principals (Sand, Garba, \& Mikailu 2011). The stakeholders" theory attempts to address the questions of which group of stakeholders merit the attention of management. The stakeholders" theory proposes that companies have a social responsibility that requires them to consider the interest of all parties affected by their actions.

\subsubsection{Stewardship Theory}

This theory presents a contrasting view to agency theory. Stewardship theory asserts that, there will not be any 
major agency costs, since managers are naturally trustworthy (Donaldson 1990; Donaldson \& Preston1995, cited in Aduda, Chogii \& Magutu, 2013). According to the perspective of the 'stewardship theorists, managers are inherently reliable and loyal stewards of the corporate resources entrusted to them. Managers are very good quartermaster of the organization and it is in their own interest to work to maximize corporate benefice and shareholder returns. Therefore, proponents of stewardship theory argue that firm performance is bound to a majority of inside directors and combined leadership structure (Aduda, et. al, 2013).

Stewardship theory sees a strong connection between managers striving to successfully achieve the objectives of the company, and the resulting satisfaction accorded to owners as well as other participants in the firm (Clarke 2004).

\subsubsection{Resource Dependency Theory}

While the stakeholder theory concentrates on relationships between many groups for individual profits, resource dependency theory focuses on the docket of board directors in providing access to resources needed by the company (Abdullah \& Valentine, 2009). According to this theory the primary function of the board of directors is to afford resources to the enterprise. Directors are sight as a substantial resource to the firm. When directors are considered as resource providers, various dimensions of director diversity clearly become important such as gender, experience, qualification and the like. Mallin (2007) gives a comprehensive analyze of corporate governance theories and argues that the agency approach is the most appropriate because it provides a better explication for corporate governance docket (Habash, 2010).

\subsection{Corporate Financial Performance and Corporate Governance Mechanisms}

\subsubsection{Corporate Financial Performance}

This study adopted ROA and PM as the more pragmatic indicators for use as proxies for firm performance in West African Monetary Union (WAMU) Stock Exchange. This is especially as the samples of firms that were used for the study are quoted companies in West African Monetary Union (WAMU) Stock Exchange. Therefore, ROA and PM remain preferable measures which should provide reliable result for analysis.

Return on Asset (ROA): Return on asset is an indicator of how profitable a company is related to its total assets. It gives a view as to how efficient management is at using its assets to generate earnings, that is, it measures efficiency of the business in using its assets to generate net income. It is a profitability ratio. Calculated by dividing a company's annual earnings by its total assets, ROA is displayed as a percentage. Sometimes this is referred to as "return on investment".

Return on assets is the ratio of annual net income to average total assets of a business during a financial year. Net income is the after tax income. It can be found on income statement. Average total assets are calculated by dividing the sum of total assets at the beginning and at the end of the financial year by 2 .

Total assets at the beginning and at the end of the year can be obtained from year ending balance sheets of two consecutive financial years. The formula to calculate return on assets is:

$$
R O A=\frac{\text { Annuel Net Incom }}{\text { Average } \text { Total asset }}
$$

Profit Margin (PM): Due to the samples that were used for this study from the West African Monetary Union (WAMU) Stock Exchange, operating and financing arrangement vary so much that different entities are bound to have different levels of expenditure, and the comparison with one to another has little or no meaning. Profit margin is a company's pricing strategies and how well it controls cost. Profit margin is profit after tax divided by turnover of the selected samples of firms. Thus, it is represented by:

$$
P M=\frac{\text { Profit After } \text { Tax }}{\text { Tounover }}
$$

\subsubsection{Corporate Governance Mechanisms}

Corporate governance mechanisms assure investors in corporations that they will receive adequate returns on their investments (Emmon and Schmid, 1999). This study adopts four corporate governance mechanisms namely: composition of board member, board size, CEO status and shareholding (ownership) concentration. They are succinctly explained as follows:

Composition of Board Members: Zahra and Pearce (1989) showed that boards are amongst the most venerable tools of corporate governance. A positive relationship is expected between firm performance and the proportion of outside director sitting on the board, unlike inside directors, outside director are better able to challenge the 
CEOs. It is maybe in reconnaissance of the role of exterior directors that in UK, a minimum of three outside directors is required on the board and also in the US, the regulation requires that they constitute at least two third of the board (Bhagat \& Black, 2001).

Contrary to the preceding debate in support of board structure, Laing and Weir (1999) play down their weight, stressing instead on the importance of business experience and entrepreneurship. According to them, firms managed by dynamic CEOs tend to performance better than other categories of firms.

Board Size: There is a convergence of agreement on the argument that board size is associated with firm performance. Nevertheless, contradictory findings emerge on whether it is a wide, rather than a petty board, that is more effective. For example, Yermack (1996) argues that large boardrooms tend to be slow in making decision and hence can be an obstacle to change. A second reason for the support for small board size is that directors rarely criticize the policies of top managers and that this problem tends to increase with the number of directors (Lipton \& Lorsch, 1992; Yermack 1996).

Chief Executive Officer Status (CEO's Status Duality): Many studies that have tested the separation of office of board chair from that of CEO generally sought to reduce agency costs for a firm. Kajola (2008) found a positive relationship between performance and separation of board chairman and CEO. In the line of Kajola (2008), Yermack (1996) also found that firms are more valuable when different persons occupy the CEO and board chairman. The results of the studies of (Klein, 2002), show also that boards that are structured to be independent to the $\mathrm{CEO}$ are more effective in monitoring corporate financial accounting process and therefore more valuable.

Ownership Concentration: This mechanism of ownership concentration refers to the proportion of a firms share owned by a given number of the largest shareholders. A high concentration of shares tends to create more pressure on managers to behave in ways that are value maximizing. In support of this argument, Gorton and Schmid (1996) and Shleifer and Vishy (1997) proposed that a low-lying level of ownership concentration will be associated with an increase in firm value, but that go beyond a certain level of concentration, the relationship might be negative. According to Renneboag (2000), his results are not totally in agreement with the hypothesis of a positive relationship between firm performance and ownership concentration.

\section{Methodology}

This study focuses on evaluating the empirical relationship between firm performance level and corporate governance mechanisms. The study adopts a cross-sectional research designed by analyzing listed companies on the West African monetary union (WAMU) regional financial exchange; the total of 39 listed companies in the regional financial exchange.

\subsection{Population and Sampling}

The population consists of all the companies quoted on West African Monetary Union (WAMU) and active as at $31^{\text {st }}$ December, 2015. In December 2015, there were 39 securities listed on the capital market. The populations have their annual financial report for the year end 2015.

\subsection{Sources of Data}

The data used for this study is secondary data and this data was sourced from the annual reports of the selected companies. The data was on the following variables; return on asset, profit margin, ownership concentration, composition of board members, board size and CEO status. The research has been conducted on firms listed in West African Monetary Union (WAMU).Thus a sample of 39 companies was used to collect the data.

\subsection{Model Specification}

In this study, econometric model was formulated. The model basically relates to firm performance as dependent function of selected corporate governance variables. The measures of the key variables of the research are discussed below. 
Table 1. Operationalization and measurement of variables

\begin{tabular}{|c|c|}
\hline \multicolumn{2}{|c|}{ Dependent Variables } \\
\hline Variables & Measurement \\
\hline Return on Asset (ROA) & Annual Net Income/Average Total Assets \\
\hline Profit Margin (PM) & Profit After Tax/Turnover \\
\hline \multicolumn{2}{|c|}{ Independent Variables } \\
\hline Variables & Measurement \\
\hline Composition of board members (CBM) & $\begin{array}{l}\text { Ratio of insider director (executive directors) to outsider directors } \\
\text { (non-executive directors). }\end{array}$ \\
\hline Board size (BS) & Number of directors on the board \\
\hline CEO Status (CEOS) & $\begin{array}{l}\text { A dummy variable taking "O" for separate office and for CEO from the } \\
\text { chairman and " } 1 \text { " otherwise (duality) }\end{array}$ \\
\hline Ownership Concentration (OC) & Percentage of major shareholding of shareholders \\
\hline
\end{tabular}

Source: Authors.

\subsection{Models of the Study}

\section{Model I:}

$$
R O A=\beta_{0}+\beta_{1} C B M+\beta_{2} B S+\beta_{3} C E O S+\beta_{4} O C+\varepsilon
$$

Model II:

$$
P M=\gamma_{0}+\gamma_{1} C B M+\gamma_{2} B S+\gamma_{3} C E O S+\gamma_{4} O C+\varepsilon
$$

In this study both descriptive and inferential statistics were employed. Descriptive statistics such as: mean, mode, median and standard deviation were used to describe the data while inferential statistics such as correlation and regression analyses were used to test the stated hypotheses.

\section{Results, Findings and Discussions}

This section contains the presentation, analysis and interpretation of the data collected for this study. Consequently, it entails the application of both mathematical and statistical techniques to provide the basis for the testing of the research hypotheses. This section contains the descriptive statistics, correlation result, Ordinary Least Squares regression (OLS) results as well as discussion of findings.

Table 2. Descriptive statistics

\begin{tabular}{lcccccc}
\hline \multicolumn{1}{c}{ Variables } & $\begin{array}{c}\text { Board } \\
\text { Composition }\end{array}$ & Board Size & CEO & Ownership & \multicolumn{2}{c}{$\begin{array}{c}\text { Profit } \\
\text { Margin }\end{array}$} \\
\hline Mean & 0.5700 & 6.8930 & 0.1222 & 0.2640 & 7.0673 \\
Median & 0.6000 & 9.0000 & 0.0000 & 1.0022 & 7.3000 & 5.6520 \\
Maximum & 0.8000 & 17.0000 & 1.0000 & 0.6780 & 102.500 & 78.6000 \\
Minimum & 0.3600 & 3.0000 & 0.0000 & 0.0010 & -198.500 \\
Std. Dev. & 0.1730 & 2.7622 & 0.2410 & 0.2300 & -189.5000 \\
Observations & 39 & 39 & 39 & 39 & 19.6450 \\
\hline
\end{tabular}

Source: Authors.

The analysis begins by examining the basic features of the data using descriptive statistics. In the Table 2 , the mean PM of the sampled firms is 7.0673 and the mean ROA is 6.4340. The average board size of the 39 firms used in this study is 6.8930 while the proportion of the board composition is $57 \%$. The result also indicates that $87.78 \%$ of the sampled firms have separate persons occupying the posts of the CEO and the mean ownership concentration of the sampled firms is 0.2640 . 
Table 3. Correlations (Pearson)

\begin{tabular}{|c|c|c|c|c|c|c|}
\hline Variables & $\begin{array}{c}\text { Board } \\
\text { Composition }\end{array}$ & Board Size & $\begin{array}{l}\text { CEO } \\
\text { Status }\end{array}$ & $\begin{array}{c}\text { Ownership } \\
\text { Concentration }\end{array}$ & $\begin{array}{c}\text { Profit } \\
\text { Margin }\end{array}$ & $\begin{array}{c}\text { Return on } \\
\text { Asset }\end{array}$ \\
\hline Return on Asset & 1 & & & & & \\
\hline Profit Margin & $0.4811 * *$ & 1 & & & & \\
\hline Board Size & $0.2311^{*}$ & $0.3411^{* *}$ & 1 & & & \\
\hline Board Composition & $0.1988 * *$ & $0.3111^{* *}$ & 0.0432 & 1 & & \\
\hline CEO Status & 0.1110 & 0.0031 & -0.1311 & -0.1354 & 1 & \\
\hline Ownership Concentration & -0.0311 & 0.0655 & -0.1022 & -0.1675 & $0.273^{* *}$ & 1 \\
\hline
\end{tabular}

Source: Authors.

According to the result of the Table 3, Return on Asset (ROA) is positively related to Board Size (0.2311), Board Composition (0.1988) and CEO Status (0.1110). The relationship between Return on Asset (ROA) and Board Size are significant at $\mathrm{P}<0.05$, but Return on Asset (ROA and Board Composition are significant at $\mathrm{P}<0.10$.The result also shows that the CEO Status is insignificant. But we have a negative and insignificant relationship correlation between Return on Asset (ROA) and ownership concentration (-0.0311).

Furthermore, Profit Margin (PM) is positively correlated with Board Size (0.3411), Board Composition (0.3111), CEO Status (0.0031) and Ownership Concentration (0.0655). However, only Board Size and Board Composition are significant at $\mathrm{P}<0.10$. There are no high correlations of 0.90 or above in the result shown in Table 3 . However, the highest coefficient of correlation found is below the cut-off of 0.80 for the collinearity problem. Hence, collinearity and multicollinearity do not present data problems in this research.

Two indices of financial performance namely: Return on Asset (ROA) and Profit Margin (PM) were utilized in the analyses. The results are shown below in Table 4 and 5.

Table 4. Model I: Return on Asset (ROA)

\begin{tabular}{lccc}
\hline Variable & Coefficient & t-statistic & Probability \\
\hline C & -22.3245 & -3.1123 & 0.0026 \\
CBM & 27.4567 & 3.0301 & 0.0123 \\
BS & 2,1134 & 2.3245 & 0.0087 \\
CEOS & 6.4343 & 1.5733 & 0.1043 \\
OC & -0.0120 & 0.0000 & 1.0000 \\
R-squared & & 0.0848 & \\
Adjusted R-squared & & 0.0595 & \\
F-statistic & & 3.2146 & \\
Prob (F-statistic) & & 0.0067 & \\
Akaike info criterion & & 9.2011 & \\
Schwarz criterion & & 9.1110 & \\
Durbin-Watson stat & & 2.0133 & \\
\hline
\end{tabular}

Source: Authors.

Table 4 shows the regression result, the explanatory (independent) variables: Board Size, Board Composition, CEO Status and Ownership Concentration were regressed on Return on Asset (ROA) an R2 value of 0.0848 is noticed. Given the value of Adjusted R2 of 0.0595 indicates that the independent variables (Board Size, Board Composition, CEO Status and Ownership Concentration) explain $5.95 \%$ of the systematic variation in the dependent variable (ROA). The result reveals that only Board Composition and Board Size are significant at $\mathrm{P}<0.05$. However, CEO Status and Ownership Concentration are not significant as P-Values are greater than $5 \%$.The sign of the coefficients of the variables are all positive except ownership concentration which has the negative coefficient of -0.0120 .

The F-statistic of 3.2146 is significant at $\mathrm{P}<0.01$ for model I. This means that there is a statistical significant relationship between the independent variables and the dependent variable as a group. And, the Durbin-Watson statistics of 2.0133 indicate the absence of first order serial correlation.

In a summary manner, the first model reveals that only Board Composition and Board Size are significant 
corporate governance variables that explain financial performance.

In table 5, the result shows that Board Size, Board Composition, CEO Status and Ownership Concentration were regressed on profit margin (PM) and R2 value of 0.1560 is noticed. Given the value of Adjusted R2 of 0.1447 indicates that the independent variables jointly explain $14.47 \%$ of the systematic variation in the dependent variable (PM). Only Board Composition and Board Size are significant at $\mathrm{P}<0.05$ with positive sign for all coefficients of the variables. Like the first model, F-statistic of 8.5531is significant at $\mathrm{P}<0.01$ for model II. This means that there is a statistical significant relationship between the independent variables (CBM, BS, CEOS and OC) and the dependent variable Profit Margin (PM).

Moreover, the Durbin-Watson statistic of 2.0395 for this second model reveals the absence of first order serial correlation.

Summarily, the mode 1II reveals that only Board Composition and Board Size are significant corporate governance variables that explain financial performance. However, profit margin is a better proxy of financial performance as it shows higher Adjusted R2, SIC and AIC.

Table 5. Model II: Profit Margin (PM), regression results

\begin{tabular}{lccc}
\hline Variable & Coefficient & t-statistic & Probability \\
\hline C & -47.8723 & -3.9823 & 0.0001 \\
CBM & 45.6523 & 3.7901 & 0.0011 \\
BS & 4.1134 & 4.3645 & 0.0000 \\
CEOS & 4.8723 & 0.5733 & 0.3243 \\
OC & 17.1354 & 2.2100 & 0.1320 \\
R-squared & & 0.1560 & \\
Adjusted R-squared & & 0.1447 & \\
F-statistic & 8.5531 & \\
Prob (F-statistic) & & 0.0001 & \\
Akaike info criterion & & 9.2614 & \\
Schwarz criterion & 9.3667 & \\
Durbin-Watson stat & & 2.0395 & \\
\hline
\end{tabular}

Source: Authors.

\section{Further Analysis of the Study}

Firstly, the study reveals that there is a positive and significant relationship between composition of board member and firm performance for the two models. The implication of this study is that as the company maintains sizeable number of internal and external directors, the financial performance of the company is expected to increase. The results are consistent with the study of Mehran (1995); Pinteris (2002); Weisbach (1988), and Adekunle and Aghedo (2014). This is consistent with our first hypothesis.

Secondly, there is a positive and significant relationship between board size and firm performance. It can be deduced that as companies maintain appropriate board size, the financial performance of the firm would increase. This finding corroborates the result of Yermack (1996) and Adekunle and Aghedo (2014) who examined the relationship between board size and financial performance and concluded that the smaller the board size the better the performance, and proposed an optimal board size of ten or fewer. This validates our second hypothesis

Moreover, the study showed a positive but insignificant relationship between CEO status and financial performance. This is also conform with the study of Yermack (1996) and Adekunle and Aghedo (2014) who show that firms are more valuable when the CEO and the chairman of the board positions are occupied by different persons. This is also consistent with our third hypothesis.

Finally, there is no significant relationship between ownership concentration and financial performance. A high concentration of shares tends to create more pressure on managers to behave in ways that are value-maximizing. At low levels of ownership concentration, an increase in concentration will be associated with an increase in firm value, but beyond certain level of concentration, the relationship might be negative Gorton and Schmid (1996); Shleifer and Vishny (1997); Adekunle and Aghedo (2014). Our last hypothesis is not validated.

\section{Conclusion}

In respect of board structure, board size is significantly and positively related to firm performance, implying that, 
in a large size board, the diversity of insiders' opinion has a negative impact on making decisions, which is detrimental to firm performance.

We have also significantly and positively relationship between the Chief Executive Officer Status (CEO Status) and financial performance. This is also conform with the study of Yermack (1996) and Adekunle and Aghedo (2014) who show that firms are more valuable when the CEO and the chairman of the board positions are occupied by different persons.

But, there is no significant relationship between ownership concentration and financial performance. A high concentration of shares tends to create more pressure on managers to behave in ways that are value-maximizing. At low levels of ownership concentration, an increase in concentration will be associated with an increase in firm value, but beyond certain level of concentration, the relationship might be negative Gorton and Schmid (1996); Shleifer and Vishny (1997); Adekunle and Aghedo (2014).

Anchored on the above summary of findings and conclusion, the following recommendations are made:

- Ensure greater compliance with legal and regulatory requirements since it was found to be performance enhancing. This would ultimately translate to significant positive effect on performance via substantial two mechanisms, internal and external corporate governance.

- $\quad$ All the listed firms in the West African Monetary Union (WAMU), should ensure that majority of their board members are independent in the sense that the directors are not employees of the company and do not depend on it for their livelihood so that they can fearlessly and honestly monitor the activities of the CEO and other directors;

- Ensure optimal compliance with laid down rules, optimal board composition proactive practices to push for significant positive effect on performance of corporate governance practices in the sector.

- Evolve additional corporate governance practices to promote the positive impact of board composition and proactive practices of the boards and managements.

- The board size should be in line with corporate size and activities in all the listed firms in the West African Monetary Union (WAMU).

- The office of CEO should be separated from Chairman of the Board to improve self-sacrifice, wholeness, accountability and honesty which are the principles of good corporate governance.

- The listed firms in the West African Monetary Union (WAMU) should look beyond corporate governance structure and incorporate these and other corporate governance practices into their management policies within their internal and external business environments.

\section{References}

Abdullah, H., \& Valentine, B. (2009). Fundamental and ethics theories of corporate governance. Middle Eastern Finance and Economics, 4, 89-96.

Abdul-Qadir, A., \& Kwambo, M. L. (2012). Corporate governance and financial performance of banks in the post consolidation period in Nigeria. International Journal of Social Science and Humanity Studies, 4(2), 27-36.

Adedokun, S. (2003). Corporate governance and organizational performance. In A. Oladimeji (Ed), Issues in Corporate Governance. Lagos: Financial Institutions Training Centre.

Agbonifoh, B. A. (1999). Business ethics. In A. U. Inegbenebor, \& B. E. Osaze (Eds.), Introduction to business. Lagos: Malthouse Press Limited.

Bollaert, H., Daher, H., Derro, A., \& Dupire-Declerk, M. (2010). Corporate governance and performance of French listed companies. IESEG School of Management.

Chiou, J. R., Hsiung, T. C., \& Kao, L. F. (2002). A Study of the Relationship Between Financial Distress and Collateralized Shares. Taiwan Accounting Review, 3, 79-111.

Dalton, D., Daily, C., Johnson, J., \& Ellstrand, A. (1999). Number of directors and financial performance: A meta-analysis. Academy of Management Journal, 42, 674-686. http://dx.doi.org/10.2307/256988

Fama, E., \& Jensen, M. C. (1983). Separation of ownership and control. Journal of Law and Economics, 26, 301-326. http://dx.doi.org/10.1086/467037

Glossary. (2013). Glossary of definition of corporate governance. Retrieved on July 14, 2013 from http://www.google.com 
Gompers, P., Ishii, J., \& Metrick, A. (2003). Corporate governance and equity prices. The Quarterly Journal of Economics, 118(1), 107-155. http://dx.doi.org/10.1162/00335530360535162

Gorton, G., \& Schmid, F. (1996). Universal banking and performance of german firms. Working paper 5453, National Bureau of Economic Research, Cambridge, Massachusetts USA.

Habbash, M. (2010). The effectiveness of corporate governance and external audit on constraining earnings management practice in the UK. Doctoral thesis, Durham University. Retrieved June 12, 2013 from http://etheses.dur.ac.uk/448/

Hussin, N., \& Othman, R. (2012). Code of corporate governance and firm performance. British Journal of Economics, Finance and Management Sciences, 6(2).

Jensen, M. C. (1993).The modern industrial revolution, exit, and the failure of internal control systems. Journal of Finance, 48, 831-880. http://dx.doi.org/10.1111/j.1540-6261.1993.tb04022.x

Kao, L. F., Chiou, J. R., \& Chen, A. (2004). The Agency Problem,Firm Performance and Monitoring Mechanisms: The Evidence from Collateralized Shares in Taiwan. Corporate Governance: An International Review, 12, 389-402. http://dx.doi.org/10.1111/j.1467-8683.2004.00380.x

Kim, D., \& Rasiah, D. (2010). Relationship between corporate governance and corporate performance in Malaysia during the pre and post Asian financial crisis. European Journal of Economics, Finance \& Administrative Sciences, (21), 40-59.

Lipton, M., \& Lorsch, J. W. (1992). A modest proposal for improved corporate governance. Business Lawyer, 481, 59-77

Love, I. (2011). Corporate governance and performance around the world: What we know and what we don't know. The World Bank Research Observer, 261, 42-70. http://dx.doi.org/10.1093/wbro/lkp030

Maher, M., \& Andersson, T. (1999). Corporate governance: Effects on firm performance and economic growth. OECD, 1-51.

Mallin, C. A. (2007). Corporate Governance (2nd ed.). New York: Oxford.

Okeahalam, C., \& Akinboade, A. (2003). A review of corporate governance in Africa: Literature, Issues and Challenges. Paper prepared for the Global Corporate Governance Forum 15 June.

Onyenankeya, K. (2003). Financial crime: The Nigerian experience. Nigerian Stock Market Manual, 25-33.

Renneboag, L. (2000). Ownership, managerial control and governance of companies listed on the Brussels stock exchange. Journal of Banking and Finance, 2412, December 1959-1995. http://dx.doi.org/10.1016/s0378-4266(99)00128-4

Sanda, A., Mikailu, A., \& Garba, T. (2005). Corporate governance mechanisms and firm financial performance in Nigeria. African Economic Research Consortium, Research Paper, 149, Kenya Regal Press.

Shleifer, A., \& Vishny, R. W. (1997). A survey of corporate governance. Journal of Financial Economics, 522, 737-783. http://dx.doi.org/10.1111/j.1540-6261.1997.tb04820.x

Yermack, D. (1996). Higher market valuation of companies a small board of directors. Journal of Financial Economics, 40, 185-202. http://dx.doi.org/10.1016/0304-405X(95)00844-5

\section{Copyrights}

Copyright for this article is retained by the author(s), with first publication rights granted to the journal.

This is an open-access article distributed under the terms and conditions of the Creative Commons Attribution license (http://creativecommons.org/licenses/by/3.0/). 